\title{
Revitalization of Patterns and Events in Traditional Living Houses to Conserve Rural Settlement Architecture Case Study: Jatiluwih Village - Tabanan Bali
}

\author{
I Wayan Runa, Anak Agung Gede Raka, I Nyoman Warnata \\ \{sarwagunawayan@gmail.com\} \\ Universitas Warmadewa, Bali, Indonesia
}

\begin{abstract}
This research is aims to solve problems that are relevant to the needs of rural communities. It is expected to facilitate preservation of residential architecture, especially houses, since rural settlements grow with the times. The study uses qualitative methods related to unique contextual factors. Additionally, the research focuses on transcendental matters or multiple realities felt and experienced by the local community. Based on the characteristics of the study object, the paradigm used is phenomenology. The research unit / observation area was in the form of a whole home setting. The scale research unit of houses in Jatiluwih Village was expected to produce information on values / ideas about the local wisdom of traditional houses. These values are expected to be developed for the preservation model of residential houses influenced by modernization or become tourist attraction objects. The variables observed at the village scale include patterns and forms of traditional houses. When examining houses located in the garden, the continuous (core) and changing parts related to the socio-cultural and physical activities are observed. In Year 1, this research is expected to produce Publications on Methods of Preservation of residential architecture that raise local wisdom in International Journals. The results of this study is supposed to be presented in a national forum. In Year 2, it is expected to produce Publications on Prototypes, policies, manuals on how to implement settlement preservation, and additional output in the form of Textbooks. The results serves as a guideline to stakeholders in revitalizing the patterns and forms of houses as tourist accommodation in line with the establishment of Jatiluwih Village as a tourism village. National strategic research in the region is said to be successful in case it meets the achievement indicators. This include the concept of housing development that elevates the values of local wisdom, design and Budget Plan (RAB), market, and preservation manuals.
\end{abstract}

Keyword: Architecture, Local Wisdom, Traditional House

\section{Introduction}

The number of islands in Indonesia according to data from the Ministry of Home Affairs of the Republic of Indonesia in 2004 (Erwin Alwazir, 2013) is 17,504. 7,870 of them already have names, while 9,634 do not have names. In tens of thousands of islands it has 74,000 villages, while 32,000 villages are in the lagging category with a population of around 57.5 million. In Bali from ancient times until the time of copper inscriptions, there were villages and autonomous village associations. Village charter usually lists the privileges of village communities which are regularly renewed at each inauguration of the new king. Every time there is something new, it must be known by the village community. After Majapahit took control of Bali, villages were investigated to determine which privileges could still be maintained. Villages that do not have a charter or an inscription are classified into domestic government (apanage). The village made a mistake, as the charter sentence was withdrawn and then thrown into the sea. That has caused them no longer to have written evidence of these privileges (Liefrinck, 1890). Fig 1. The Unitary State of the Republic of Indonesia has 17,504 islands and 74,000 villages (Erwin Alwazir, 2013). According to Korn (1932), in general the villages in Bali can be divided into two types, namely the mountainous Bali village (Bali Aga) and the plain Bali village. The mountainous Bali village is an older village, mostly located in the mountains, fewer in number, but has more physical variation than the plain Bali village, and still exhibits 
many pre-Hindu (Hindu-Bali) characteristics. The village of Bali plateau is a younger type of village, mostly located in the plains area of southern Bali and much influenced by Hindu-Javanese (Majapahit).

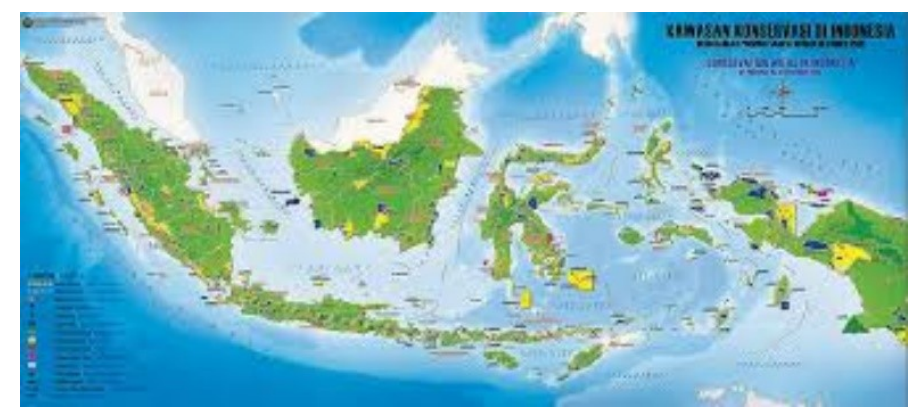

Fig.1.The Unitary State of the Republic of Indonesia has 17,504 islands and 74,000 villages (Erwin Alwazir, 2013).

The physical characteristics of the mountainous village that stand out are the communal open space stretching in the direction of the kaja-kelod (the mountains) dividing the village into two parts. The open space uses river stone pavement and rises towards the mountains or hills. Then the physical characteristics of plain villages are crossing roads, shared public facilities such as meeting halls, shrines, and sometimes dwelling houses of nobles are around the crossing of the road (Parimin, 1986). The uniqueness and diversity of village settlements is the main attraction of life now, which considers that attraction can bring added value or economic progress. The uniqueness that is so much needs to be investigated to find out the magnitude of the attractiveness of many parties. Mountain villages also have residential homes that are more varied compared to the plain Bali village houses. It is no exaggeration if a house in a flat Bali village is said to be the "housing" of Bali. The Bali Provincial Government through the Office of Tourism and Culture since 2012 has a tourism village development program. In 2016 Tabanan Regency received a total of 16 locations. The villages chosen to be developed into tourist villages include Sudimara Village, Tua Marga, Pinge, Belimbing, Antapan, Kerobokan, Mekar Sari, Tegal Lingga, and Jatiluwih which are valid for 5 years. With the establishment of tourist villages, it is hoped that the economy can be rolled out in the village, thereby reducing the flow of urbanization and helping alleviate poverty. In addition to the advantages of natural tourism, cultural tourism, agro tourism and ecotourism are also developed.

Jatiluwih village in Penebel District, Tabanan Regency, Bali Province was chosen as a national strategic research site because it has several advantages. First, Jatiluwih Village is one of the old villages in Bali with a distinctive pattern and form of residential architecture. Second, the settlements of Jatiluwih Village surrounded by very beautiful rice terraces are visited by domestic and foreign tourists. Third, because of the peculiarities of settlements and their natural beauty, Jatiluwih Village is designated as one of the World Cultural Heritage Sites by UNESCO. Fourth, in person and institution (Faculty of Engineering, Warmadewa University), Jatiluwih Village has been frequently visited so that understanding of the peculiarities of the village and subsequent development becomes easier.

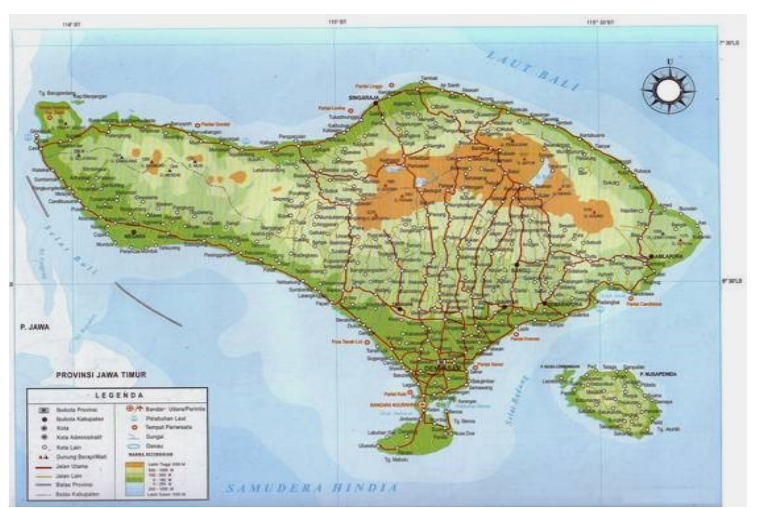

Fig.2. Location of Jatiluwih Tabanan Village - Bali (Korn, 1932). 


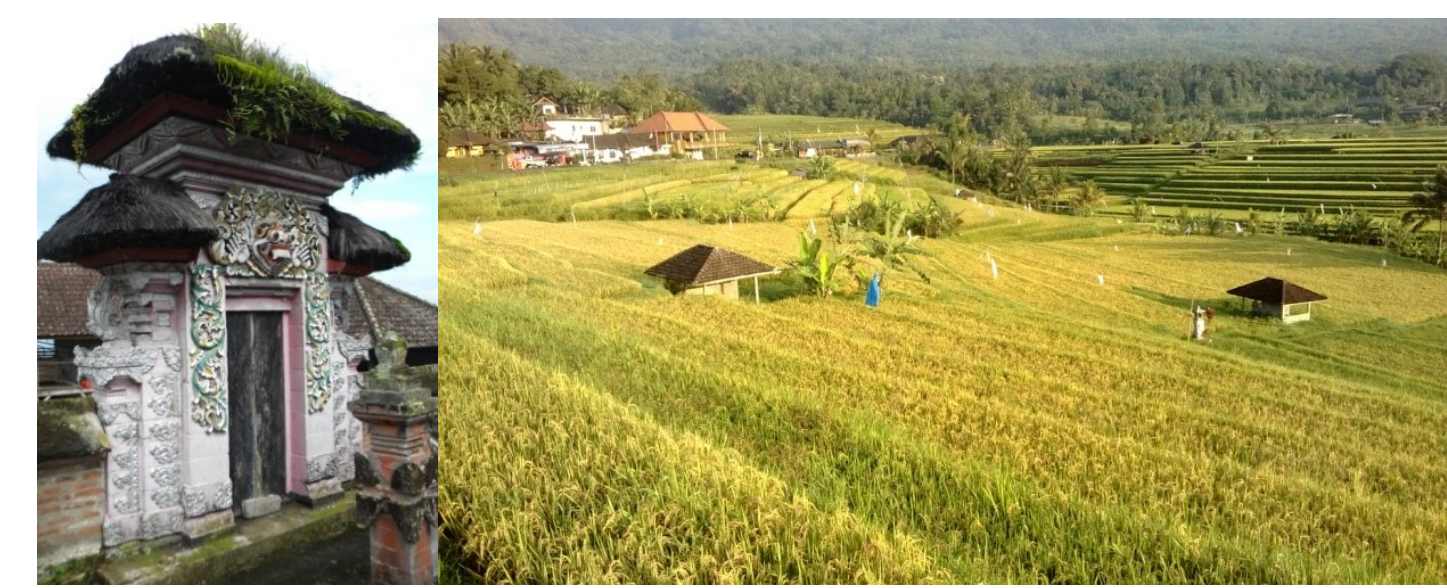

Fig.3. The attractiveness of the village environment, namely traditional buildings and rice terraces which are visited by many domestic and foreign tourists (Runa, 2013).

UNESCO World Heritage Sites (UNESCO's World Heritage Sites) are a special place such as National Parks, Forests, Mountains, Lakes, Islands, Deserts, Buildings, Complexes, Regions, Rural Areas and Cities that have been nominated for UNESCO-managed International World Heritage programs World Heritage Committee, consisting of 21 groups (21 state parties) selected by the General Assembly in a 4-year contract. A World Heritage Site is a place of culture and nature, as well as objects that matter to mankind and become a legacy for the next generation. This program aims to catalog, name, and preserve places that are very important to become the world's human heritage. Registered places can obtain funds from the World Heritage Fund under certain conditions. This program was created through a meeting on the Maintenance of World Cultural and Natural Heritage followed by the UNESCO General Conference on 16 November 1972. The cultural activities of the Jatiluwih people continue to grow in line with the development of the times starting from prehistoric times to modern times. At first they as a small community lived in groups in the main village. Furthermore, the population is increasing so that the village becomes more crowded and the development of settlements is very limited due to the topography of the village. Now residents have started living in the garden (pakubon). The study of the cultural activities of the Jatiluwih Village community in Penebel District, Tabanan Regency - Bali is important to find the concept of preserving ancient village settlements in Bali. This is done considering that Balinese people generally have experienced structural changes (transformation), before agrarian societies now led to non-agricultural, especially small industries / tourism. The transformation that occurs in mountain village communities will certainly affect the patterns and forms of mountain village settlements. Based on the background description of the problem above, then for the next 1 (one) year research problems can be formulated, namely:

a. What is the change in the pattern and form of architecture of a residential house in Jatiluwih Village?

b. What is the concept of housing development that elevates the values of local wisdom in serving tourists?

\section{Method}

This study took the object of a traditional residential house located in Jatiluwih Village. Jatiluwih Village is one of the ancient villages or mountain villages in Central Bali including Penebel District, Tabanan Regency, Bali. The distance of Jatiluwih Village from the Capital of the Province is approximately 47 kilometers, or 9 kilometers north of the center of Penebel District. The village is connected by paved roads, located on a plateau around 1,740 meters above sea level with 150 melimeters of rainfall per year and the topography of Jatiluwih Village is around 50\%. Jatiluwih village has its own uniqueness with regard to houses, where each family lives in a large yard lined up with each other. The common Bale together is in the middle near the holy place. In one residential unit there are bale meten, paon, and barn. The boundary between houses is also unique, namely there is no massive wall as a barrier like a house in a flat area of Bali. In line with the times, there are now also many houses built in gardens that are quite far from the center of the main village or village. This research is planned to be held for 2 (two) years, starting from January 2018 to December 2019 in the center of the village to obtain traditional values related to cultural activities living or living. This research has a lot to do with value systems, concepts, perceptions, diversity, uniqueness, local wisdom and people's beliefs about something outside themselves. In addition, the research carried out also has a lot to do with transcendental matters or multiple realities that are felt and strongly 
trusted by the local community, but its existence is difficult to explain. In accordance with the characteristics of the study object (research problem), the paradigm used in this study is phenomenology. According to Lincoln and Guba (1985), phenomenology (naturalistic) emphasizes the "natural" context, which is a context of overall roundness, which cannot be understood by making isolation or elimination so that it is independent of the context. A phenomenon can only be captured in its entirety and is a form of reciprocal role (interactive), not just a linear causal relationship.

The workings of the qualitative method (phenomenology) are as follows. the design is general, flexible, and develops in the research process. Aims to gain understanding of meaning, develop theory, and describe complex reality. Human instruments (own researchers), notebooks, voice recorders, and do not need a research assistant. Qualitative data with data sources based on involved observation (participation), individual documents, and in-structured in-depth interviews. Small samples are taken purposively, continuous analysis, inductive, looking for patterns, models, or thematic. Short and general design proposals, allegedly relevant problems, no hypotheses, research focus is often written after data has been collected from the research field. Qualitative research is closely related to unique (unique) contextual factors, so that each context is handled in terms of its own context. In this study, the research unit / observation area was in the form of a whole home setting. The scale research units of houses in Jatiluwih Village and Kasongan Village are expected to produce identification or information on values / ideas / ideas about the local wisdom of traditional houses. These values are expected to be developed for the preservation model of residential houses that have the influence of modernization or become tourist attraction objects. "Variables" observed at the village scale are patterns and forms of traditional houses. When researching houses located in the garden, the "variables" observed are continuous parts (core) and changing parts that are related to the socio-cultural and physical activities of the house. In Year 1 this research is expected to produce mandatory outcomes in the form of Publications in the International Journal about changes in patterns and forms of residential architecture, as well as the concept of housing development that elevates the values of local wisdom in Jatiluwih Village and Kasongan Village. In the 2nd Year this research is expected to produce prototypes (maket) of housing development, policies and settlement preservation manuals, ways of socialization, and additional output in the form of Textbooks. Every year it is also expected to produce papers that have been presented nationally. National strategic research in Jatiluwih Village and Kasongan Village can be said to be successful if it meets the achievement indicators, namely: the concept of housing development that elevates the values of local wisdom, design and Budget Plan (RAB), models (prototypes), preservation manuals, and communities feel that preservation is an urgent need (in socialization).

\section{Results And Discussion}

Year 1 the product of national strategic research in the village of Jatiluwih in the form of the concept of developing a residential house that elevates the values of local wisdom. Based on field research conducted on Sunday, August 26, 2018 at the residence of Mr. I Nyoman Dastra (west of the road) and Bapak Kuasa (east of the road), the results of the following research can be described. Viewed from the aspect of planning (macro), the area considered the most sacred is in the northeast direction for the yard which is on the west side of the road, while in the northwest for the yard which is located on the east side of the road. Then from the village road to the main orientation of Mount Batukaru. In this area usually placed a holy place (objection). In the northern part of the yard after the sanctuary is usually placed a kitchen facing south / to Natah. After natah there is usually a traditional bale and a bed that is oriented / facing center / natah. To the south near the entrance is usually placed jineng / lumbung as a place to store the results of rice fields (paddy). At the most teben, which is southwest for the yard in the west, the road or southeast for the yard in the east, the road is usually placed in the bathroom / toilet. 


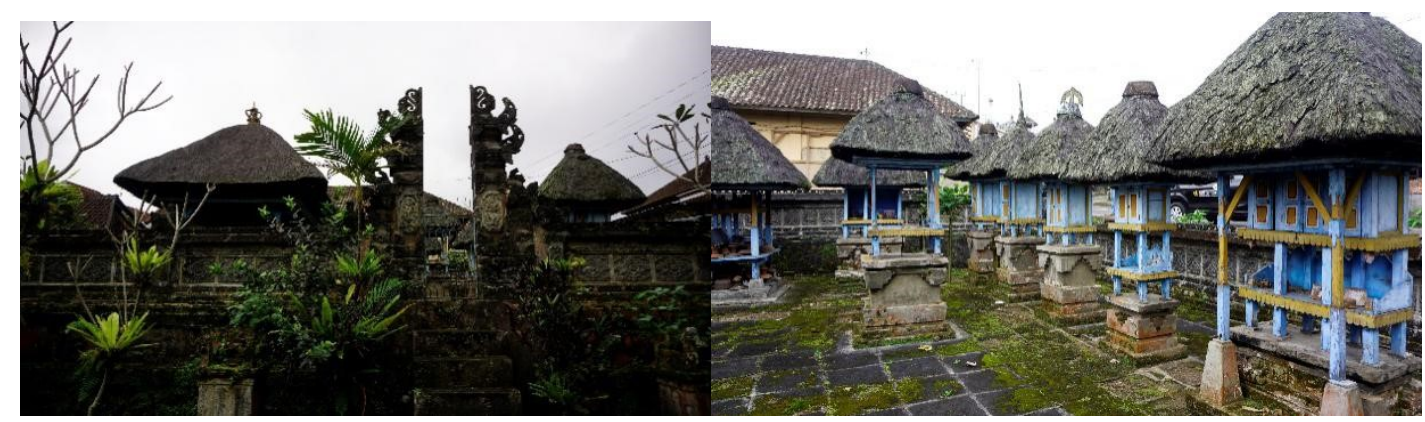

Fig 8. Building of the sanctuary (left) and dereten palinggih (right) in the sacred area (Runa, 2018).

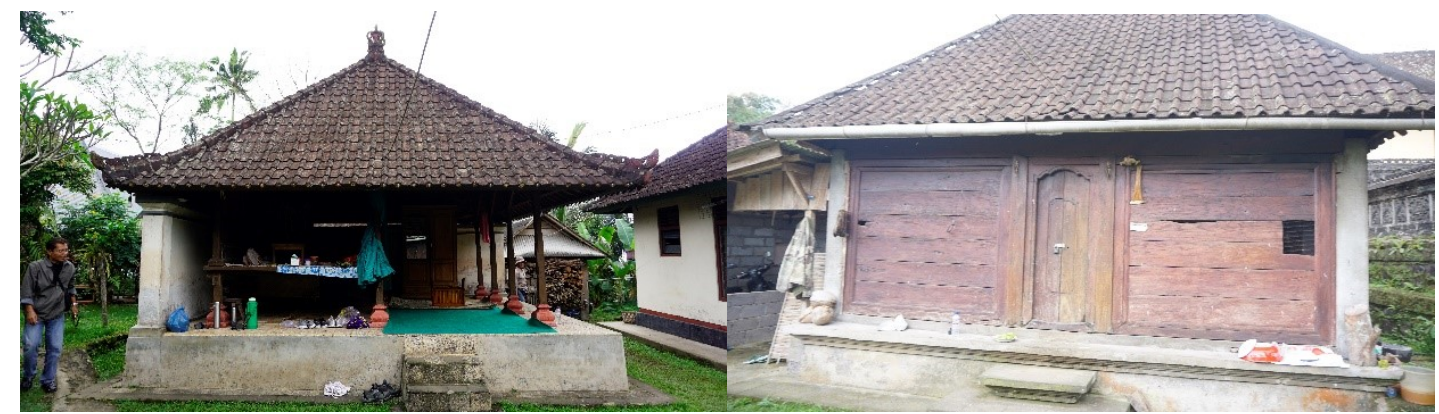

Fig 9. Traditional saka roras Bale (left) and kitchen building / paon (right) facing south / natah in the middle (Runa, 2018)

With regard to environmental utilities, the drainage of rainwater in the yard of a home is regulated according to the topography of the land which is directed westward. Clean water is all sourced from the PDAM, all residential houses also use electric lighting, while the bathroom / toilet is equipped with septictank and infiltration to deal with the waste produced.

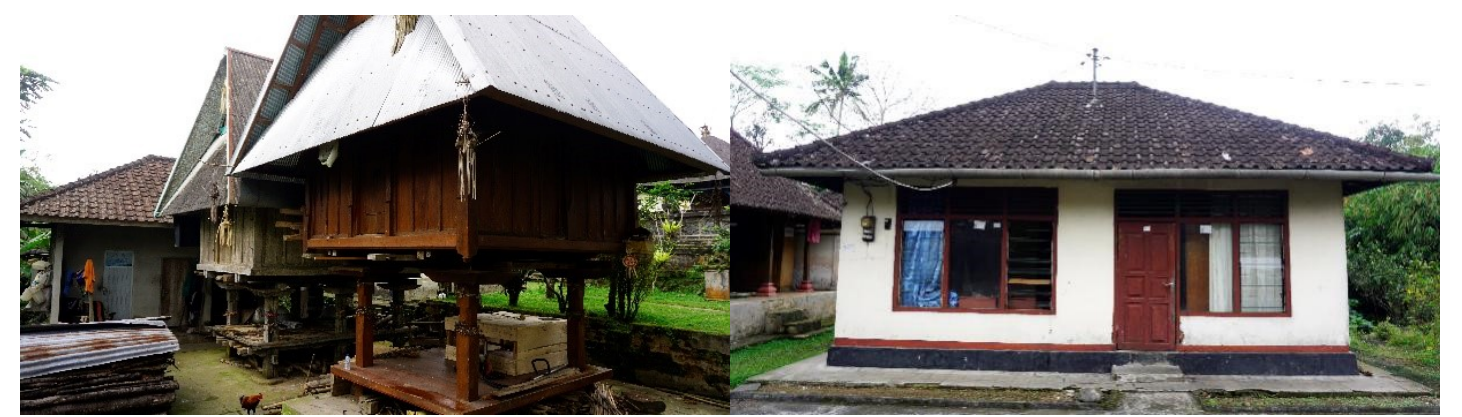

Fig 10. Granary building (left) as a place to store rice yields (paddy) and meten bale buildings as beds (right) facing north / center (Runa, 2018).

Judging from the design aspect (micro), all building units use basic shapes in terms of 4 . Building units are arranged linearly (patterned) with natah as the center of orientation in the center. The main structures of buildings, especially super structures, mostly use a skeletal system with wood material, sub-structure with a local system with stone material, while the upper structure uses a truss system with a roof cover using tile or zinc material. Except for the roof cover of the sacred building which mostly uses roof cover from palm fiber. Because in general Jatiluwih Village has a cold climate, there are no building units that use air conditioning. In the morning until noon as optimal as possible the building units use natural lighting. Site plan drawings, layout plans, and residential plot pieces that are used as objects of this research are either classified as "original" or those that experience the most changes can be seen in the appendix. Along with the development of the times, if you see the changes from the front / road of the village you can see the dimensions of the entrance which is about 3 meters wide. This is related to the demands of easy access in and out of the yard, where cars have now become less expensive goods in the village. Correspondingly, in the front of the yard there must also be a building unit that functions as a garage for cars and motorbikes. Then the yard has also been mostly hardened with pc, concrete or paving material so that if the rainy season arrives, the drainage in the front yard is overloaded to channel rainwater. Family sanctuaries do not undergo many changes where the layout is in accordance with the standard local values (near the road). There are only a few changes related to the use of black stone material in the sub and super structure. 
In building units whether it is related to the kitchen or living quarters, there have been many changes, especially those related to style. Many styles here are related to the use of building materials such as marble, brick, stone and various types of ornaments. In short, many have followed the style like most buildings in urban areas.

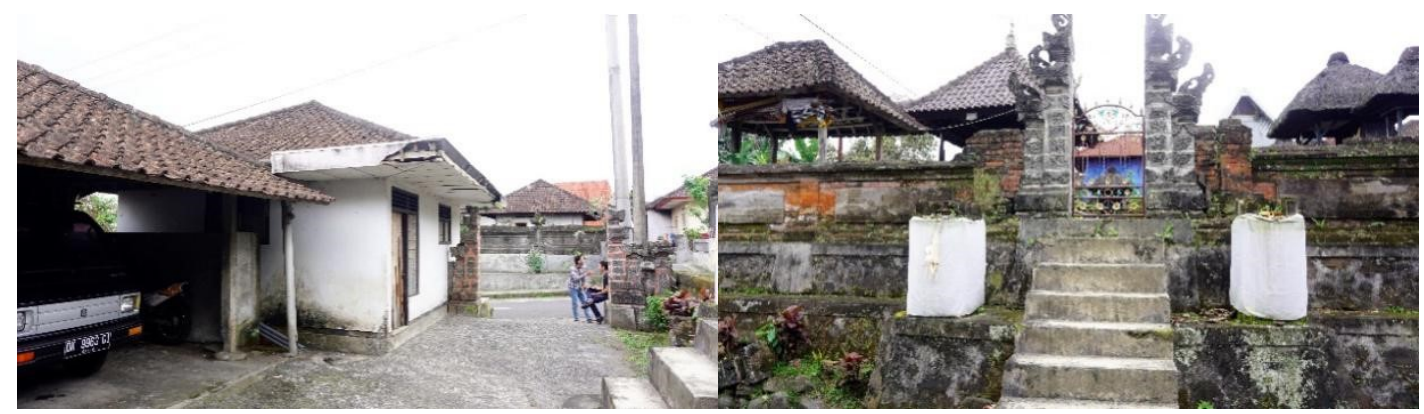

Fig 11. The dimensions of the yard entrance (left picture) have become wider so that the access to and from the yard by car or motorcycle becomes smooth. The right picture is a family objection that has not changed much in terms of style (Runa, 2018).

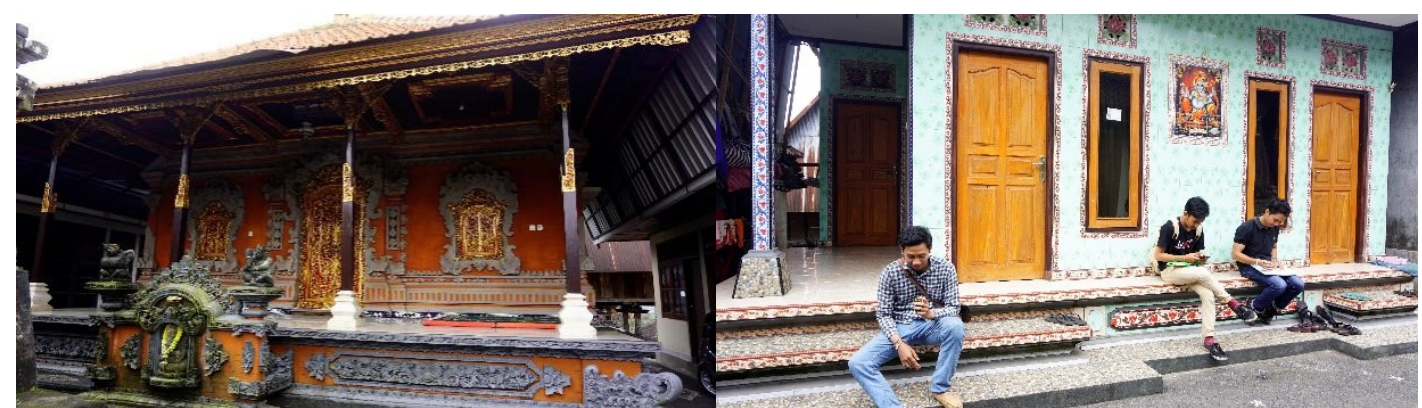

Fig 12. Style of building units that function as beds or kitchens have used a lot of building materials such as in urban areas, namely: marble, brick, stone with various types of ornaments (Runa, 2018).

In a large enough yard which is marked by still leaving empty land or gardens in the back of the yard, lately there have been residents who use it for the function of lodging or temporary accommodation for tourists. This is very reasonable because Jatiluwih Village is designated as one of the World Cultural Heritage in Bali. However, based on the results of research in the field, it seems that the newly developed function has not been very encouraging. This can be seen from the condition of the building seen in the field as being poorly maintained. A comprehensive study is needed to develop the land of this village in order to produce optimal results, whether it is related to the number and model of building units that are developed in accordance with the characteristics of tourists who come and the potential of Jatiluwih Village both physical, natural and cultural.

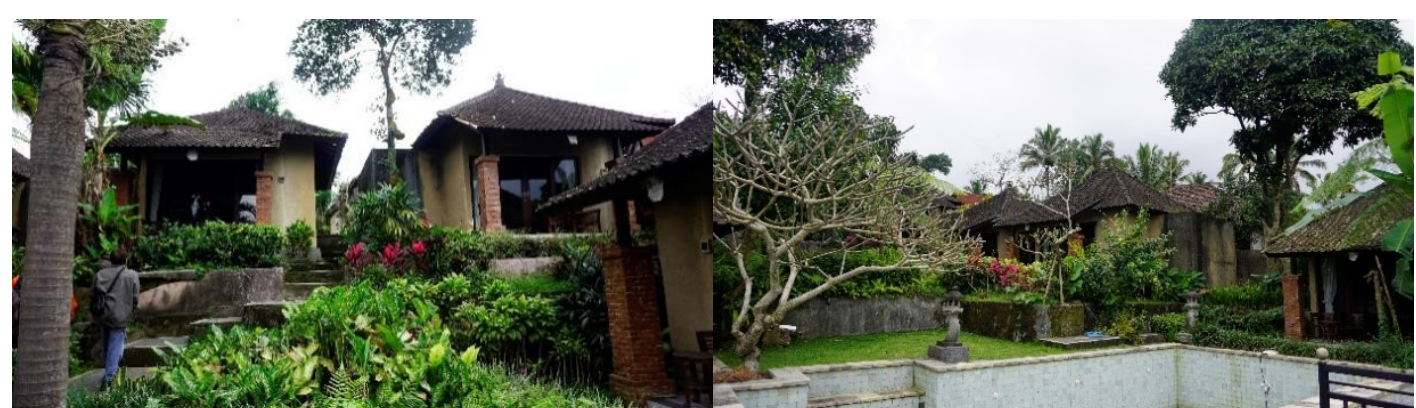

Fig 13. Development of village-owned homesteads to become accommodation places equipped with ponds, but cannot function optimally as expected (Runa, 2018).

Furthermore, the development of facade of lodging building units seems to be developed from the style of local building units that have simple or not many uses of decorative shapes with rectangular basic shapes 
with relatively small area and limasan roof shape with roof coverings of tile types because the quality materials are so good and the price is relatively expensive. The orientation of building units remains in the middle direction in the middle. Outer space elements also take advantage of local potential whether it is related to trees, shrubs, and pavement elements.

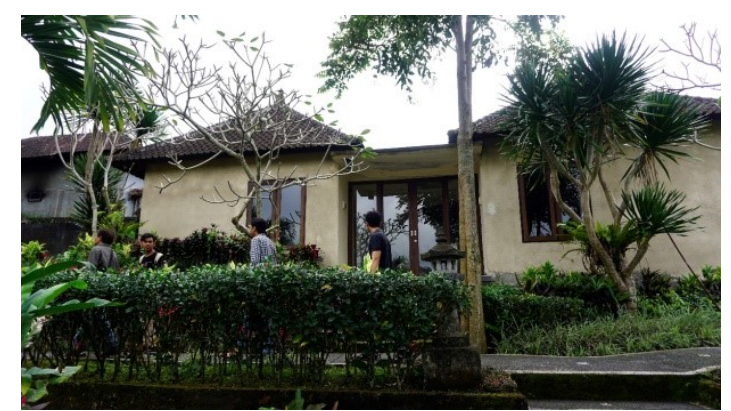

Fig 14. Facade of lodging building units developed from the style of a local building unit that has a simple impression with a basic rectangular shape and a limasan roof shape. (Runa, 2018).

\section{Conclusion}

Based on the discussion above, we can conclude the following. The pattern of houses in Jatiluwih Village can be said to be fixed ie linear pattern with natah in the center as an orientation center. It's just that in terms of dimensions the dimensions of the Natah appear to be slightly smaller. The architectural form of houses in general follows architectural styles in urban areas that are related to the use of materials and decorative items. The concept of housing development that elevates the values of local wisdom in serving tourists is to maintain the natah pattern and the basic form of rectangles for building units. In addition the typical local values are upstream-teben, where the upstream area leads to the main road in front and then leads to Mount Batukaru in the north, while the teben area instead leads to areas with lower topography to the south.

\section{References}

[1] Erwin Alwazir, 2013, 1 Miliar Per Desa, Negara Diambang Bangkrut, Opini, 27 October pkl. 15:45, http://kompasianaku.blogspot.com.

[2] Korn, V.E., 1932, Hukum Adat Bali, terjemahan Het Adatrecht van Bali, II, 's Gravenhage: G. Naeff.

[3] Lincoln, Y.S., Guba, E.G., 1985, Naturalistic Inquiry, Sage Publications, Beverly Hills California, London, New Delhi.

[4] Parimin, A.P., 1986, Fundamental Study on Spatial Formation of Island Village: Environmental Hierarchy of Sacred-Profane Concept in Bali, Unpublished Disertation, Osaka University, Japan.

[5] Situs Warisan Dunia UNESCO, Dari Wikipedia Bahasa Indonesia, Ensiklopedia Bebas, Kamis, 16 Mei 2013, pukul 23.00 Wita. 